\title{
Molecular heterogeneity in malignant peripheral nerve sheath tumors associated with neurofibromatosis type 1
}

\author{
Laura Thomas ${ }^{1}$, Victor-Felix Mautner ${ }^{2}$, David N Cooper ${ }^{1}$ and Meena Upadhyaya ${ }^{1 *}$
}

\begin{abstract}
Neurofibromatosis type-1 (NF1), resulting from NF1 gene loss of function, is characterized by an increased risk of developing benign and malignant peripheral nerve sheath tumors (MPNSTs). Whereas the cellular heterogeneity of NF1-associated tumors has been well studied, the molecular heterogeneity of MPNSTs is still poorly understood. Mutational heterogeneity within these malignant tumors greatly complicates the study of the underlying mechanisms of tumorigenesis. We have explored this molecular heterogeneity by performing loss of heterozygosity $(\mathrm{LOH})$ analysis of the NF1, TP53, RB1, PTEN, and CDKN2A genes on sections of 10 MPNSTs derived from 10 unrelated NF1 patients. LOH data for the TP53 gene was found to correlate with the results of p53 immunohistochemical analysis in the same tumor sections. Further, approximately $70 \%$ of MPNSTs were found to display intra-tumoral molecular heterogeneity as evidenced by differences in the level of $\mathrm{LOH}$ between different sections of the same tumor samples. This study constitutes the first systematic analysis of molecular heterogeneity within MPNSTs derived from NF1 patients. Appreciation of the existence of molecular heterogeneity in NF1-associated tumors is important not only for optimizing somatic mutation detection, but also for understanding the mechanisms of NF1 tumorigenesis, a prerequisite for the development of specifically targeted cancer therapeutics.
\end{abstract}

Keywords: Neurofibromatosis type 1, Malignant peripheral nerve sheath tumors, Molecular heterogeneity, TP53

\section{Introduction}

Neurofibromatosis type 1 (NF1) (MIM 162200) is an autosomal dominant disorder affecting approximately 1 in 4,000 people worldwide [1]. NF1 is characterized by variable clinical features including benign cutaneous neurofibromas and plexiform neurofibromas in addition to pigmentary abnormalities comprising café-au-lait macules, Lisch nodules of the iris, and axillary and inguinal freckling. Learning difficulties and orthopedic problems also occur in up to $50 \%$ of individuals with NF1 [2]. Malignant complications are a less frequent but potentially much more serious manifestation of NF1. These often lead to premature death in individuals with NF1 and include malignant peripheral nerve sheath tumors (MPNSTs) which occur in approximately $10 \%$ to $15 \%$ of patients [3], pheochromocytomas, brain tumors, optic

\footnotetext{
* Correspondence: upadhyaya@cardiff.ac.uk

'Institute of Medical Genetics, School of Medicine, Cardiff University, Cardiff CF14 4XN, UK

Full list of author information is available at the end of the article
}

gliomas, gastrointestinal stromal tumors, and breast carcinomas [4].

The NF1 gene, located at 17q11.2, encodes neurofibromin, a 2818 amino acid protein which is expressed at a high level in the brain and central nervous system [4]. Neurofibromin is a highly conserved RAS-GAP which negatively regulates Ras signaling [5-7] and the multiple downstream effectors activated by Ras, such as the PI3K and the MAPK (mitogen-activated kinase) signaling cascades that are involved in regulating cell proliferation, DNA synthesis, and apoptosis. The loss of neurofibromin function due to NF1 gene inactivation therefore results in the constitutive activation of many of these down-regulated systems leading to increased cell proliferation and an increased likelihood of tumorigenesis.

In line with the tumor suppressor role of the NF1 gene, mutational inactivation of both NF1 alleles is required to change the phenotype of the cell: a first (inherited) mutation in one NF1 allele is followed by the somatic loss of the remaining wild-type $N F 1$ allele via a
Ciomed Central

(c) 2012 Thomas et al.; licensee BioMed Central Ltd. This is an Open Access article distributed under the terms of the Creative Commons Attribution License (http://creativecommons.org/licenses/by/2.0), which permits unrestricted use, distribution, and reproduction in any medium, provided the original work is properly cited. 
number of different mutational mechanisms. Loss of heterozygosity $(\mathrm{LOH})$, for example, represents a common form of loss of function of the wild-type NF1 allele in somatic cells such as Schwann cells which form neurofibromas, owing to the presence of an inherited NF1 gene lesion on the other allele. $[8,9] \mathrm{LOH}$ is known to be caused by a number of mechanisms including deletions of genetic material and the loss of a whole chromosome by nondisjunction with or without reduplication. However, mitotic recombination has been demonstrated to be the most common event accounting for $\mathrm{LOH}$ in NF1-associated tumors [9].

In addition to NF1 gene mutations, a number of other loci are also known to be involved in the process of NF1 tumorigenesis. Thus, additional somatic mutations have been identified in NF1-associated MPNSTs that affect several genes encoding proteins involved in cell cycle regulation: TP53, RB1, CDKN2A [10-17], and PTEN [18]. Alterations in TP53 and RB1 have also been identified in plexiform neurofibromas [19] and more recently in cutaneous neurofibromas from patients with a high tumor burden [20]. These genetic alterations act so as to promote cellular proliferation as a consequence of CDKN2A loss and to bring about abnormal cell cycle arrest mediated by DNA damage and aberrant apoptosis as a consequence of the loss of TP53 and RB1.

Tumor heterogeneity is a notoriously challenging aspect of cancer biology, responsible for introducing very significant complexity into both the study of the underlying mechanisms of tumor development and the therapeutic context [21-23]. Tumor heterogeneity has been modeled using a number of different biomarkers to identify the extent of heterogeneity at the cellular, molecular, and genome architectural levels [24,25]. Cellular heterogeneity is a well-established feature of NF1-associated tumors, particularly in benign cutaneous neurofibromas in which only the Schwann cells harbor NF1 mutations, although the tumors also contain fibroblasts, mast cells, perineural cells, and axons [26]. The tumor microenvironment is also known to impact upon the development of NF1-associated tumors, with mast cells a likely contributor to neurofibroma development [27]. As with benign neurofibromas, malignant NF1-associated tumors are known to be heterogeneous in nature, invariably containing diverse subpopulations of tumor cells, including benign and malignant cells, fibroblasts, and infiltrating inflammatory cells [26]. At the molecular level, malignant tumors are recognized as being highly heterogeneous in terms of both their accumulated genetic mutations and their phenotypic [CDKN2A, TP53, RB1] expression profiles $[13,15,16]$.

Analysis of molecular and cellular heterogeneity using a variety of methods promises to generate important new insights into tumor biology as well as the underlying processes of tumorigenesis. This is the first study to comprehensively determine the level of molecular heterogeneity in a panel of MPNSTs derived from patients with NF1. It is hoped that this will provide further understanding of the molecular heterogeneity of malignant tumors in the context of the underlying background cellular and genome architectural heterogeneity. Furthermore, such studies may allow both therapeutic sensitivities and the efficacy of potential drug treatments to be comprehensively evaluated.

\section{Materials and methods \\ Patients}

Ten unrelated patients, all exhibiting the NIH diagnostic criteria for NF1 (reviewed by Upadhyaya [1]) were analyzed in this study. Germline mutations have been detected in 7 of the 10 patients (Table 1); however, full clinical details were not available from all patients. A total of 10 MPNSTs derived from these patients were carefully and individually macrodissected to yield clean sections which were in turn further subdivided. The number and size of the various sections and subsections were mainly dependent upon the size of the original tumor (Table 1 and Additional file 1: Supplementary Figure S1). DNA was extracted from all sections of tumor samples and corresponding constitutional (blood) samples by means of the phenol/chloroform extraction method [28]. This study obtained approval from the appropriate institutional review boards. All patients involved provided their informed consent.

\section{LOH analysis}

$\mathrm{LOH}$ analysis was performed on all sections derived from the 10 MPNSTs and their corresponding lymphocyte DNA samples with a panel of fluorescently tagged microsatellite markers located within the five genes investigated: NF1 (D17S799, J1J2, IVS27, EV120, IVS38, 3/NF1-1, D17S798, D17S250, and D17S1822) [28], TP53 (D17S796, TP53 Inv, TP53 c.72, TP53 Exon 6, D17S938, and D17S804) [29,30], RB1 (D13S118, D13S153, D13S917, RB1.2, RB1.26, and D13S119) [31,32], CDKN2A (D9S1751, D9S942, D9S304, and D9S748) [33,34], and PTEN (D10S2491, D10S215, exon 3, and exon 8) [35]. Molecular heterogeneity was assessed by noting differences in the level of $\mathrm{LOH}$ between different sections of the same tumor sample.

Markers were analyzed by means of an ABI 3100 genetic analyzer using Genotyper and Genescan software (Applied Biosystems, Warrington, UK) [28]. Allele loss in a tumor was scored if the area under one allelic peak in the tumor section was reduced relative to the other allele, after correction of the relative peak areas against the corresponding lymphocyte DNA sample. For LOH to be confirmed, at least two adjacent markers were 
Table 1 Analysis of molecular heterogeneity with respect to NF1, TP53, RB1, CDKN2A, and PTEN in 10 MPNSTs

\begin{tabular}{|c|c|c|c|c|c|c|c|c|}
\hline Tumor & Tumor number & Tumor section & Tumor subsection & NF1 & TP53 & $R B 1$ & PTEN & CDKN2A \\
\hline \multirow[t]{47}{*}{1} & T196.22 & A & 1 & $\mathrm{LOH}$ & $\mathrm{LOH}$ & $\mathrm{LOH}$ & $\mathrm{LOH}$ & $\mathrm{LOH}$ \\
\hline & & & 2 & $\mathrm{LOH}$ & $\mathrm{LOH}$ & $\mathrm{LOH}$ & $\mathrm{LOH}$ & $\mathrm{LOH}$ \\
\hline & & & 3 & $\mathrm{LOH}$ & $\mathrm{LOH}$ & $50 \% \mathrm{LOH}$ & $\mathrm{LOH}$ & $\mathrm{LOH}$ \\
\hline & & & 4 & 12 & 12 & 12 & 12 & 12 \\
\hline & & & 5 & $\mathrm{LOH}$ & $\mathrm{LOH}$ & $50 \% \mathrm{LOH}$ & $\mathrm{LOH}$ & $\mathrm{LOH}$ \\
\hline & & & 6 & $\mathrm{LOH}$ & $\mathrm{LOH}$ & $\mathrm{LOH}$ & $\mathrm{LOH}$ & $\mathrm{LOH}$ \\
\hline & & & 7 & $\mathrm{LOH}$ & $\mathrm{LOH}$ & $\mathrm{LOH}$ & $\mathrm{LOH}$ & $\mathrm{LOH}$ \\
\hline & & & 8 & $\mathrm{LOH}$ & $\mathrm{LOH}$ & $50 \% \mathrm{LOH}$ & $50 \% \mathrm{LOH}$ & $\mathrm{LOH}$ \\
\hline & & & 9 & 12 & $\mathrm{LOH}$ & 12 & $\mathrm{LOH}$ & $\mathrm{LOH}$ \\
\hline & & & 10 & 12 & $\mathrm{LOH}$ & 12 & $\mathrm{LOH}$ & $\mathrm{LOH}$ \\
\hline & & B & 1 & $\mathrm{LOH}$ & $50 \% \mathrm{LOH}$ & $50 \% \mathrm{LOH}$ & $50 \% \mathrm{LOH}$ & 12 \\
\hline & & & 2 & $\mathrm{LOH}$ & $50 \% \mathrm{LOH}$ & $50 \% \mathrm{LOH}$ & $50 \% \mathrm{LOH}$ & 12 \\
\hline & & & 3 & $\mathrm{LOH}$ & $50 \% \mathrm{LOH}$ & $50 \% \mathrm{LOH}$ & $50 \% \mathrm{LOH}$ & 12 \\
\hline & & & 4 & $\mathrm{LOH}$ & $50 \% \mathrm{LOH}$ & $50 \% \mathrm{LOH}$ & $50 \% \mathrm{LOH}$ & 12 \\
\hline & & & 5 & $50 \% \mathrm{LOH}$ & $50 \% \mathrm{LOH}$ & $50 \% \mathrm{LOH}$ & $50 \% \mathrm{LOH}$ & 12 \\
\hline & & & 6 & $\mathrm{LOH}$ & $50 \% \mathrm{LOH}$ & $50 \% \mathrm{LOH}$ & $50 \% \mathrm{LOH}$ & 12 \\
\hline & & & 7 & $\mathrm{LOH}$ & $50 \% \mathrm{LOH}$ & $50 \% \mathrm{LOH}$ & $50 \% \mathrm{LOH}$ & 12 \\
\hline & & & 8 & $\mathrm{LOH}$ & $50 \% \mathrm{LOH}$ & $50 \% \mathrm{LOH}$ & $50 \% \mathrm{LOH}$ & 12 \\
\hline & & & 9 & $\mathrm{LOH}$ & $50 \% \mathrm{LOH}$ & $50 \% \mathrm{LOH}$ & $50 \% \mathrm{LOH}$ & 12 \\
\hline & & & 10 & $\mathrm{LOH}$ & $50 \% \mathrm{LOH}$ & $50 \% \mathrm{LOH}$ & $50 \% \mathrm{LOH}$ & 12 \\
\hline & & C & 1 & $\mathrm{LOH}$ & $\mathrm{LOH}$ & $50 \% \mathrm{LOH}$ & $\mathrm{LOH}$ & 12 \\
\hline & & & 2 & $\mathrm{LOH}$ & $\mathrm{LOH}$ & $50 \% \mathrm{LOH}$ & $\mathrm{LOH}$ & 12 \\
\hline & & & 3 & $\mathrm{LOH}$ & $\mathrm{LOH}$ & $50 \% \mathrm{LOH}$ & $\mathrm{LOH}$ & 12 \\
\hline & & & 4 & $\mathrm{LOH}$ & $\mathrm{LOH}$ & $50 \% \mathrm{LOH}$ & $\mathrm{LOH}$ & 12 \\
\hline & & & 5 & 12 & $\mathrm{LOH}$ & 12 & $50 \% \mathrm{LOH}$ & $50 \% \mathrm{LOH}$ \\
\hline & & & 6 & $\mathrm{LOH}$ & $\mathrm{LOH}$ & $50 \% \mathrm{LOH}$ & $\mathrm{LOH}$ & $50 \% \mathrm{LOH}$ \\
\hline & & & 7 & $\mathrm{LOH}$ & $\mathrm{LOH}$ & $50 \% \mathrm{LOH}$ & $\mathrm{LOH}$ & $50 \% \mathrm{LOH}$ \\
\hline & & & 8 & $\mathrm{LOH}$ & $\mathrm{LOH}$ & $50 \% \mathrm{LOH}$ & $\mathrm{LOH}$ & $50 \% \mathrm{LOH}$ \\
\hline & & & 9 & $\mathrm{LOH}$ & $\mathrm{LOH}$ & $50 \% \mathrm{LOH}$ & $\mathrm{LOH}$ & $50 \% \mathrm{LOH}$ \\
\hline & & & 10 & $\mathrm{LOH}$ & $\mathrm{LOH}$ & $50 \% \mathrm{LOH}$ & $\mathrm{LOH}$ & $50 \% \mathrm{LOH}$ \\
\hline & & D & 1 & $\mathrm{LOH}$ & $\mathrm{LOH}$ & $50 \% \mathrm{LOH}$ & $\mathrm{LOH}$ & $50 \% \mathrm{LOH}$ \\
\hline & & & 2 & $\mathrm{LOH}$ & $\mathrm{LOH}$ & $50 \% \mathrm{LOH}$ & $50 \% \mathrm{LOH}$ & 12 \\
\hline & & & 3 & $\mathrm{LOH}$ & $\mathrm{LOH}$ & $50 \% \mathrm{LOH}$ & $\mathrm{LOH}$ & $\mathrm{LOH}$ \\
\hline & & & 4 & $\mathrm{LOH}$ & $\mathrm{LOH}$ & $50 \% \mathrm{LOH}$ & $\mathrm{LOH}$ & $\mathrm{LOH}$ \\
\hline & & & 5 & $\mathrm{LOH}$ & $\mathrm{LOH}$ & $50 \% \mathrm{LOH}$ & $\mathrm{LOH}$ & $\mathrm{LOH}$ \\
\hline & & & 6 & $\mathrm{LOH}$ & $\mathrm{LOH}$ & $50 \% \mathrm{LOH}$ & $\mathrm{LOH}$ & $\mathrm{LOH}$ \\
\hline & & & 7 & $\mathrm{LOH}$ & $\mathrm{LOH}$ & $50 \% \mathrm{LOH}$ & $\mathrm{LOH}$ & $\mathrm{LOH}$ \\
\hline & & & 8 & $\mathrm{LOH}$ & $\mathrm{LOH}$ & $50 \% \mathrm{LOH}$ & $\mathrm{LOH}$ & $\mathrm{LOH}$ \\
\hline & & & 9 & $\mathrm{LOH}$ & $\mathrm{LOH}$ & $50 \% \mathrm{LOH}$ & $\mathrm{LOH}$ & $\mathrm{LOH}$ \\
\hline & & & 10 & $\mathrm{LOH}$ & $\mathrm{LOH}$ & $50 \% \mathrm{LOH}$ & $\mathrm{LOH}$ & $\mathrm{LOH}$ \\
\hline & & $E$ & 1 & $\mathrm{LOH}$ & 12 & 12 & 12 & 12 \\
\hline & & & 2 & $\mathrm{LOH}$ & 12 & 12 & $50 \% \mathrm{LOH}$ & 12 \\
\hline & & & 3 & $50 \% \mathrm{LOH}$ & 12 & 12 & 12 & 12 \\
\hline & & & 4 & $\mathrm{LOH}$ & 12 & 12 & $50 \% \mathrm{LOH}$ & 12 \\
\hline & & & 5 & 12 & 12 & 12 & $0 \%$ & 12 \\
\hline & & & 6 & $50 \% \mathrm{LOH}$ & 12 & 12 & $50 \% \mathrm{LOH}$ & 12 \\
\hline & & & 7 & $50 \% \mathrm{LOH}$ & 12 & 12 & $0 \%$ & 12 \\
\hline
\end{tabular}


Table 1 Analysis of molecular heterogeneity with respect to NF1, TP53, RB1, CDKN2A, and PTEN in 10 MPNSTs (Continued)

\begin{tabular}{|c|c|c|c|c|c|c|c|c|}
\hline & & & 8 & $\mathrm{LOH}$ & 12 & 12 & 12 & 12 \\
\hline & & & 9 & $\mathrm{LOH}$ & 12 & 12 & 12 & 12 \\
\hline & & & 10 & $\mathrm{LOH}$ & 12 & 12 & 12 & 12 \\
\hline 2 & T516 & $A$ & 1 & $\mathrm{LOH}$ & $50 \% \mathrm{LOH}$ & 12 & 12 & 12 \\
\hline & & & 2 & 12 & $50 \% \mathrm{LOH}$ & 12 & 12 & 12 \\
\hline & & B & 1 & $50 \% \mathrm{LOH}$ & $50 \% \mathrm{LOH}$ & 12 & 12 & 12 \\
\hline & & & 2 & $50 \% \mathrm{LOH}$ & $50 \% \mathrm{LOH}$ & 12 & 12 & 12 \\
\hline & & $\mathrm{C}$ & 1 & 12 & 12 & 12 & 12 & 12 \\
\hline & & & 2 & 12 & 12 & 12 & 12 & 12 \\
\hline 3 & T517 & $A$ & 1 & $\mathrm{LOH}$ & $50 \% \mathrm{LOH}$ & 12 & 12 & 12 \\
\hline & & & 2 & $\mathrm{LOH}$ & $50 \% \mathrm{LOH}$ & 12 & 12 & 12 \\
\hline & & B & 1 & $\mathrm{LOH}$ & $50 \% \mathrm{LOH}$ & 12 & 12 & 12 \\
\hline & & & 2 & 12 & 12 & $50 \% \mathrm{LOH}$ & 12 & 12 \\
\hline 4 & T518 & $A$ & 1 & 12 & $50 \% \mathrm{LOH}$ & $50 \% \mathrm{LOH}$ & 12 & 12 \\
\hline & & & 2 & $\mathrm{LOH}$ & 12 & $50 \% \mathrm{LOH}$ & 12 & $50 \% \mathrm{LOH}$ \\
\hline & & B & 1 & $\mathrm{LOH}$ & $50 \% \mathrm{LOH}$ & 12 & 12 & 12 \\
\hline & & & 2 & 12 & 12 & 12 & 12 & 12 \\
\hline & & C & 1 & 12 & 12 & 12 & 12 & 12 \\
\hline & & & 2 & 12 & 12 & 12 & 12 & 12 \\
\hline 5 & T519 & $A$ & 1 & 12 & $50 \% \mathrm{LOH}$ & $50 \% \mathrm{LOH}$ & 12 & 12 \\
\hline & & & 2 & $50 \% \mathrm{LOH}$ & $50 \% \mathrm{LOH}$ & $50 \% \mathrm{LOH}$ & 12 & 12 \\
\hline & & B & 1 & $50 \% \mathrm{LOH}$ & $50 \% \mathrm{LOH}$ & 12 & 12 & 12 \\
\hline & & & 2 & $50 \% \mathrm{LOH}$ & $50 \% \mathrm{LOH}$ & $50 \% \mathrm{LOH}$ & 12 & 12 \\
\hline 6 & T521 & A & 1 & $\mathrm{LOH}$ & 12 & 12 & 12 & 12 \\
\hline & & & 2 & $\mathrm{LOH}$ & 12 & 12 & 12 & 12 \\
\hline & & $B$ & 1 & $\mathrm{LOH}$ & 12 & 12 & 12 & 12 \\
\hline & & & 2 & $\mathrm{LOH}$ & 12 & 12 & 12 & 12 \\
\hline 7 & T522 & $A$ & 1 & $\mathrm{LOH}$ & 12 & 12 & 12 & 12 \\
\hline & & & 2 & $\mathrm{LOH}$ & 12 & 12 & 12 & 12 \\
\hline 8 & T523 & $A$ & 1 & $\mathrm{LOH}$ & 12 & 12 & 12 & 12 \\
\hline & & & 2 & $\mathrm{LOH}$ & 12 & 12 & $\mathrm{LOH}$ & 12 \\
\hline 9 & T524 & $A$ & 1 & $\mathrm{LOH}$ & 12 & 12 & 12 & $\mathrm{LOH}$ \\
\hline & & & 2 & $\mathrm{LOH}$ & 12 & 12 & 12 & $\mathrm{LOH}$ \\
\hline 10 & T525 & A & 1 & $\mathrm{LOH}$ & 12 & 12 & 12 & 12 \\
\hline & & & 2 & $\mathrm{LOH}$ & 12 & 12 & 12 & 12 \\
\hline & & B & 1 & $\mathrm{LOH}$ & 12 & 12 & 12 & $\mathrm{LOH}$ \\
\hline & & & 2 & $\mathrm{LOH}$ & 12 & 12 & 12 & $\mathrm{LOH}$ \\
\hline
\end{tabular}

LOH denotes samples in which approximately $100 \% \mathrm{LOH}$ of the second allele has occurred; $50 \% \mathrm{LOH}$ denotes samples in which approximately $50 \%$ of the second allele was lost; 12 denotes samples in which the marker was clearly present in the heterozygous state, denoting the absence of LOH. The results represent the summed data for all markers analyzed at each genetic loci (NF1, TP53, RB1, CDKN2A and PTEN).

required to exhibit a reduced signal by at least $50 \%$. Samples were deemed to display $\mathrm{LOH}$ when complete (approximately 100\%) loss of the second allele was evident. Samples exhibiting between approximately 50\% and $99 \%$ loss of the second allele were termed ' $50 \%$ LOH', whereas a marker which demonstrated no $\mathrm{LOH}$ (approximately $0 \%$ to $49 \%$ ) was simply classed as heterozygous ('1 2 ').

\section{p53 Immunohistochemical analysis}

Immunohistochemical (IHC) analysis of p53 was performed on five sections derived from five MPNSTs (T196.22, T516, T517, T518, and T519) which were found by LOH analysis to exhibit molecular heterogeneity with respect to the TP53 gene (Table 1). Immunohistochemistry was performed using a standard protocol [9]. Briefly, 5- $\mu \mathrm{m}$-thick slides were cut from blocks of 
formalin-fixed paraffin-embedded MPNST tissue using a microtome (Leica Microsystems, Wetzlar, Germany). Deparaffination was completed in ethanol and xylene prior to antigen recovery which was performed using boiling citrate buffer. Endogenous peroxidase was blocked with 3\% hydrogen peroxide, while goat serum (Vector Labs, Peterborough, UK) was used in the blocking step. A $100-\mu l$ pre-diluted mouse anti-p53 monoclonal primary antibody (Launch Diagnostics, Kent, UK) was used as supplied and added to each slide and incubated at $4{ }^{\circ} \mathrm{C}$ overnight. Each slide was then incubated with $100 \mu \mathrm{l} \mathrm{sec-}$ ondary antibody (Vector Labs) for $30 \mathrm{~min}$ and subsequently with $100 \mu \mathrm{l} \mathrm{ABC}$ peroxidase (Vector Labs) for 30 min. DAB (Vector Labs) was added to each slide to allow the color to develop. Slides were dehydrated and mounted with DPX (VWR).

\section{Results}

\section{LOH analysis}

Varying sizes of 10 MPNST tumors, derived from 10 different individuals, were independently sectioned, and the LOH of five genes (NF1, TP53, RB1, CDKN2A, and $P T E N)$ was analyzed for each section. Germline mutations were detected in 7 of the 10 patients. Although this is a relatively small sample, the germline mutation does not appear to correlate with the level of molecular heterogeneity. $\mathrm{LOH}$ of the NF1 gene was identified in all 10 tumors. In addition, $\mathrm{LOH}$ was noted for the TP53 gene (five tumors: T196.22, T516, T517, T518, and T519), the RB1 gene (four tumors: T196.22, T517, T518, and T519), the CDKN2A gene (four tumors: T196.22, T518, T524, and T525), and the PTEN gene (two tumors: T196.22 and T523) (Table 1, Figure 1, and Additional file 2: Supplementary Table S1). In only 2 of the 10 tumors (T521 and T522) was LOH not found in at least one of the four loci other than NF1 (i.e. TP53, RB1, CDKN2A or PTEN). Further, 7 of the 10 tumors $(70 \%)$ were found to exhibit intra-tumoral molecular heterogeneity with respect to at least one gene, as defined by a varying level of $\mathrm{LOH}$ within the same tumor (T196.22, T516, T517, T518, T519, T523, T525; i.e., between the subsections). Additional cytogenetic analysis was not available to confirm the LOH identified.

Some of the larger tumors (e.g., T521) were found to exhibit no molecular heterogeneity, whereas some smaller tumors (e.g., T523) displayed molecular heterogeneity albeit only with respect to a specific gene. Additionally, five of the tumors analyzed in this study were known to be high grade (T196.22, T517, T519, T522, and T525). Four of these high grade tumors in our cohort exhibited molecular heterogeneity (viz. T196.22, T517, T519, and T525), whereas such heterogeneity was absent in the remaining sample graded as high (T522). For the remaining samples, details on the grade of tumor were unknown.
The extent of $\mathrm{LOH}$ in the NF1 gene was also found to vary between sections of the same tumor. Thus, some sections displayed $\mathrm{LOH}$ over the entire NF1 gene and surrounding regions, whereas other sections of the same tumor only exhibited $\mathrm{LOH}$ within a portion of the NF1 gene. Details of the extent of $\mathrm{LOH}$ in each tumor are given in Additional file 2: Supplementary Table S1.

\section{p53 Immunohistochemical analysis}

IHC analysis of the tissue distribution of p53 was found to correlate broadly with the results of the LOH analysis (Figure 2). Thus, different sections of the five MPNST tumors analyzed were found to display differences in staining for p53 that closely matched the presence or absence of LOH for the TP53 gene (Table 1). For example, sections A, C, and D of T196.22 displayed complete LOH of the TP53 gene in the majority of MPNST sections, and this was reflected in higher p53 expression as seen by IHC in these samples (Figure 2B,C). Conversely, section E (T196.22) showed no p53 expression by IHC peroxidase staining, and this section was found not to display any LOH (Figure 2D). Additionally, section B (T196.22) showed lower levels of staining (Figure 2B) than that of T196.22 section $\mathrm{C}$ (Figure 2C) but more than that of T196.22 section E (Figure 2D). These results correlate with those of the $\mathrm{LOH}$ analysis in which section T196.22 section B was found to have 50\% LOH, but section T196.22 section $\mathrm{C}$ had 100\% LOH and section E (T196.22) had no LOH. p53 Positivity by IHC has previously been reported in $60 \%$ of MPNSTs, whereas neurofibromas are p53 immunonegative [36].

\section{Discussion}

Cellular heterogeneity is a well-known complication in the analyses of NF1-associated tumors. By contrast, heterogeneity at the molecular level in NF1-associated tumors has scarcely been addressed. In this study, we set out to determine the extent of molecular heterogeneity within and between 10 MPNSTs, derived from 10 unrelated NF1 patients, by determining the differences in the levels of LOH at the NF1, TP53, RB1, CDKN2A, and $P T E N$ gene loci. The results of this study indicated that $70 \%$ of the MPNST tumors studied exhibit molecular heterogeneity between sections of the same tumor sample. This heterogeneity was especially evident in the case of those sections from the same tumor which were anatomically adjacent to each other prior to dissection but which had nevertheless been found to differ with respect to the degree of $\mathrm{LOH}$. Indeed, some sections were found to be entirely devoid of $\mathrm{LOH}$ for all five gene loci analyzed but were located beside sections exhibiting complete LOH for one or more of these genes (e.g., T196.22 section A4). Prior to dissection, in a number of the MPNST tumor sections under study, there were clearly 


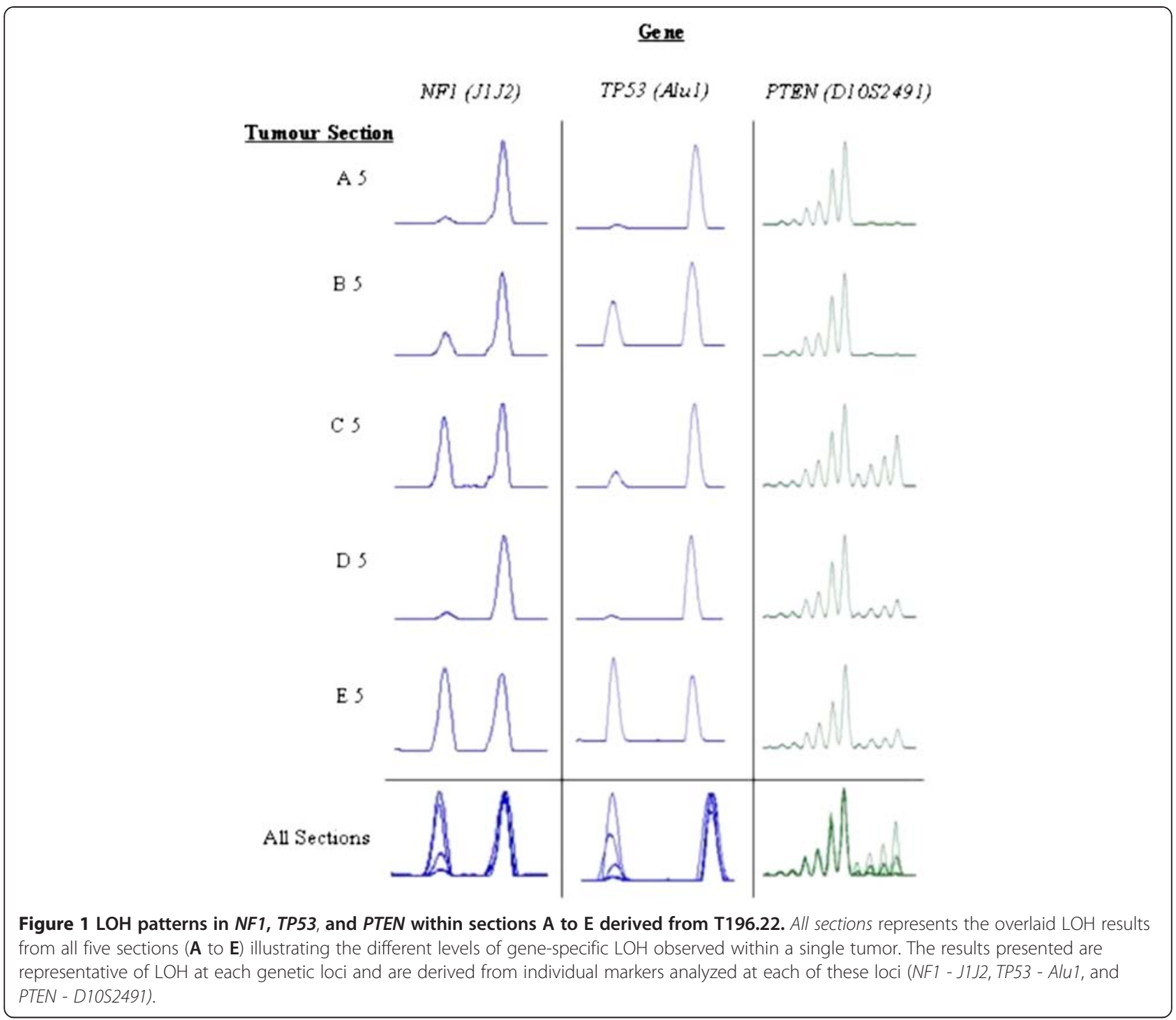

defined centrally located tumor portions (T196.22 subsection 5 A to E, T516 section B, T518 section B). These areas corresponded to the sections in which different levels of LOH and subsequently TP53 staining were identified (T196.22 section B5, T196.22 section C5, T196.22 section E5; Figure 2).

The observation that TP53 LOH correlates directly with the p53 expression, as demonstrated here, has been observed in previous studies $[37,38]$. However, the precise relationship between TP53 LOH and p53 protein expression remains unclear since some studies have identified p53 expression in tumors which have no TP53 LOH. This may be explicable in terms of the presence of two TP53 alleles, one mutant and the other wild-type in a given cell type, resulting in the production of both wildtype and mutant p53 protein. As a consequence, p53 may be detected by IHC even in the absence of p53 function. This suggests that in the context of evaluating tumor heterogeneity, IHC analysis is unlikely to be as reliable as the other molecular genotyping methods. IHC analysis could therefore be replaced by more accurate methods including AQUA [39,40] and tissue analysis with multiplex quantum dots (QD) [25] to yield a digital map of molecular and cellular heterogeneity to improve the sensitivity of detection and the prediction of a therapeutic response.

p53 is associated with malignant transformation in NF1-associated tumors [18] and LOH of the TP53 gene was identified in 5 of the 10 tumors under study (Table 1 , Additional file 2: Supplementary Table S1). TP53 has also been found to manifest in intra-tumoral molecular heterogeneity with respect to its mutation in other tumor types, including breast cancer [41,42]. In pancreatic cancer, molecular heterogeneity is evident in cells with different capacities for initiating metastasis [43] suggesting that molecular heterogeneity may well prove to be 


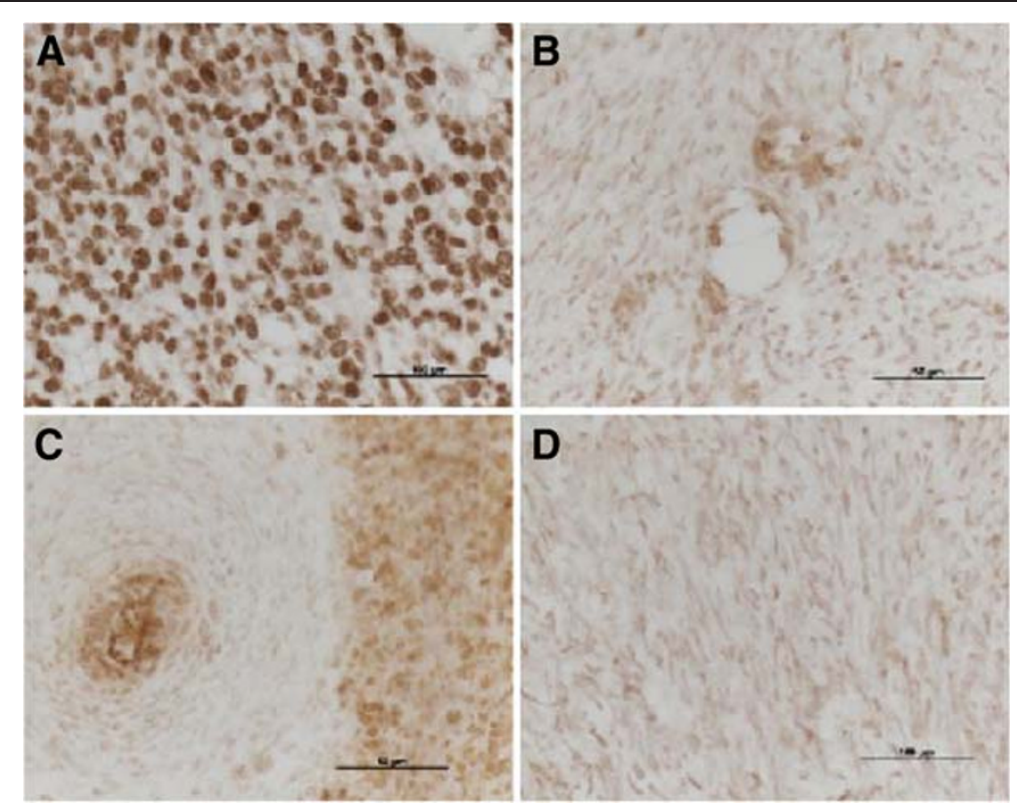

Figure 2 Immunohistochemical analysis of p53 on section 5 B,C and E (T196.22). (A) Positive control; breast carcinoma localized positive stain for p53. (B) T196.22,B5; slight localized positive p53 staining in a few cells. (C) T196.22,C5; localized positive and negative staining for p53. (D) T196.22,E5; Lack of p53 immunohistochemical staining.

the rule rather than the exception. If the molecular heterogeneity identified in this set of tumors was to emerge as relevant to MPNST development, we may have to revise our view not only of MPNST tumor biology, but also of the basic processes underlying MPNST tumorigenesis.

It might be assumed that, owing to the large size of some of the MPNST tumors, they would be divisible into a larger number of sections thereby allowing molecular heterogeneity to be assessed more clearly. However, the size of the tumor was not found to correlate with the level of molecular heterogeneity detected. It is, however, possible that intra-tumoral molecular heterogeneity could be related in some way to the grade of tumor, at least for those tumor samples analyzed here. A larger study is clearly warranted in order to determine whether these results could be replicated in a larger set of NF1-associated MPNSTs.

The pathological diagnosis of an MPNST is usually held to represent the 'gold standard' for the purposes of analysis and currently relies on the examination of not just one but a number of different sections. The results of this study, and from other previous studies on solid tumors [44-46], are broadly illustrative of the importance of careful dissection in the analysis of large tumors and suggest that in the interest of diagnostic accuracy, molecular analysis should be performed on several tumor sections alongside a pathological diagnosis. The clear implication for those studies that involve microarray analysis is that replicates across several sections would be advisable.
The results of this study therefore have important implications for molecular studies of NF1-associated tumor specimens. For example, although molecular techniques currently employed in mutation detection in large solid tumors are adequate for identifying and characterizing the underlying molecular and genetic aberrations, the potential for molecular heterogeneity means that a single dissected piece of tumor should not be assumed to be representative of the tumor as a whole; as a consequence, some somatic mutations may well be missed.

Although MPNSTs only develop in approximately 15\% of NF1 patients, they represent a frequent cause of lethal progression of the NF1 phenotype. The prognosis for individuals diagnosed with an MPNST is usually very poor; 5-year survival rates in patients with advanced nonresectable and/or metastatic MPNSTs that have exhibited a limited response to chemotherapy are in the order of $20 \%$ to $50 \%$, while 10 -year survival rates are as low as 7.5\% [47]. Treatment options for MPNSTs are currently rather limited, and complete surgical excision with clear margins is the recommended therapy for MPNSTs. A larger study is required in order to determine the full extent of molecular heterogeneity within MPNSTs in NF1 patients. However, such a study will be laborious and timeconsuming to set up especially as MPNSTs are quite rare.

Genomic instability and high intra-tumoral genetic heterogeneity may synergize so as to accelerate the evolutionary processes within the tumor leading to the development of resistance to cytotoxic and targeted anticancer drugs. Improvements clearly need to be made to the 
treatment regimes for patients with MPNSTs. The results from this study indicate that while drugs can be developed in vitro and in vivo animal studies that would be capable of targeting the genes involved in the genesis of MPNSTs, the efficacy of these drugs is likely to be somewhat limited unless the cellular, molecular, and architectural heterogeneity of the tumor are considered alongside the tumor microenvironment.

This study represents the first systematic analysis of molecular heterogeneity in MPNSTs associated with NF1. The molecular heterogeneity evident at a number of different gene loci indicates that there is an urgent need not only for the integration of molecular and morphological biomarkers in cancer diagnosis, but also for the development of specific treatments for NF1associated MPNSTs.

\section{Additional files}

Additional file1: Supplementary figure 1. Example of macrodissection of tumor 1 (T196.22). The tumor was divided into five large sections (A to E). These sections were then subdivided into 10 further sections (1 to 10).

Additional file 2: Supplementary table 1. Extent of $\mathrm{LOH}$ analysis in 5 genes (NF1, TP53, RB1, CDKN2A and PTEN) in 10 MPNSTs.

\section{Competing interests}

The authors declare that they have no competing interests.

\section{Authors' contributions}

LT performed the laboratory work and contributed to writing; V-FM provided the tumors; DNC contributed to writing; and MU conceived this study and provided overall directions. All authors read and approved the final manuscript.

\section{Acknowledgments}

We are grateful to all the patients who have participated in this study. We thank Cancer Research UK for the financial support. We would also like to thank David Viskochil for his comments on this manuscript in addition to Mark Aldred for his contributions to the immunohistochemical analysis.

\section{Author details}

'Institute of Medical Genetics, School of Medicine, Cardiff University, Cardiff CF14 4XN, UK. ${ }^{2}$ Department of Maxillofacial Surgery, University Medical Centre Hamburg-Eppendorf, Hamburg D-20246, Germany.

Received: 29 June 2012 Accepted: 8 July 2012

Published: 4 September 2012

\section{References}

1. Upadhyaya M: Neurofibromatosis type 1: diagnosis and recent advances. Expert Opin Med Diagn 2010, 4:307-322.

2. Ferner RE: The neurofibromatoses. Pract Neurol 2010, 10:82-93.

3. Upadhyaya M: Genetic basis of tumorigenesis in NF1 malignant peripheral nerve sheath tumors. Front Biosci 2011, 16:937-951.

4. Jett $\mathrm{K}$, Friedman JM: Clinical and genetic aspects of neurofibromatosis 1 . Genet Med 2010, 12:1-11

5. Upadhyaya M: Neurofibromatoses (Monographs in Human Genetics). In NF1 gene structure and NF1 genotype/phenotype correlations. Edited by Kaufmann D. Switzerland: S Karger AG; 2008:46-62.

6. Cichowski K, Jacks T: NF1 tumor suppressor gene function: narrowing the GAP. Cell 2001, 104:593-604.

7. Arun D, Gutmann DH: Recent advances in neurofibromatosis type 1. Curr Opin Neurol 2004, 17:101-105.
8. Thomas L, Spurlock G, Eudall C, Thomas NS, Mort M, Hamby SE, Chuzhanova N, Brems H, Legius E, Cooper DN, Upadhyaya M: Exploring the somatic NF1 mutational spectrum associated with NF1 cutaneous neurofibromas. Eur J Hum Genet 2012, 20(4):411-419.

9. Garcia-Linares C, Fernández-Rodríguez J, Terribas E, Mercadé J, Pros E, Benito L, Benavente Y, Capellà G, Ravella A, Blanco I, Kehrer-Sawatzki H, Lázaro C, Serra E: Dissecting loss of heterozygosity $(\mathrm{LOH})$ in neurofibromatosis type 1-associated neurofibromas: Importance of copy neutral LOH. Hum Mutat 2011, 32(1):78-90.

10. Gottfried ON, Viskochil DH, Fults DW, Couldwell WT: Molecular, genetic, and cellular pathogenesis of neurofibromas and surgical implications. Neurosurgery 2006, 58:1-16.

11. Brekke HR, Ribeiro FR, Kolberg M, Agesen $T H$, Lind GE, Eknaes M, Hall KS, Bjerkehagen B, van den Berg E, Teixeira MR, Mandahl N, Smeland S, Mertens F, Skotheim Rl, Lothe RA: Genomic changes in chromosomes 10, 16, and $\mathrm{X}$ in malignant peripheral nerve sheath tumors identify a high-risk patient group. J Clin Oncol 2010, 28:1573-1582.

12. Kourea HP, Orlow I, Scheithauer BW, Cordon-Cardo C, Woodruff JM: Deletions of the INK4A gene occur in malignant peripheral nerve sheath tumors but not in neurofibromas. Am J Pathol 1999, 155:1855-1860

13. Nielsen GP, Stemmer-Rachamimov AO, Ino Y, Moller MB, Rosenberg AE, Louis DN: Malignant transformation of neurofibromas in neurofibromatosis 1 is associated with CDKN2A/p16 inactivation. Am J Pathol 1999, 155:1879-1884.

14. Mawrin C, Kirches E, Boltze C, Dietzmann K, Roessner A, Schneider-Stock R: Immunohistochemical and molecular analysis of p53, RB, and PTEN in malignant peripheral nerve sheath tumors. Virchows Arch 2002, 440:610-615.

15. Mantripragada KK, Spurlock G, Kluwe L, Chuzhanova N, Ferner RE, Frayling IM, Dumanski JP, Guha A, Mautner V, Upadhyaya M: High-resolution DNA copy number profiling of malignant peripheral nerve sheath tumors using targeted microarray-based comparative genomic hybridization. Clin Cancer Res 2008, 14:1015-1024.

16. Cichowski K, Shih TS, Schmitt E, Santiago S, Reilly K, McLaughlin ME, Bronson RT, Jacks T: Mouse models of tumor development in neurofibromatosis type 1. Science 1999, 286:2172-2176.

17. Miller SJ, Rangwala F, Williams J, Ackerman P, Kong S, Jegga AG, Kaiser S, Aronow BJ, Frahm S, Kluwe L, Mautner V, Upadhyaya M, Muir D, Wallace M, Hagen J, Quelle DE, Watson MA, Perry A, Gutmann DH, Ratner N: Large-scale molecular comparison of human Schwann cells to malignant peripheral nerve sheath tumor cell lines and tissues. Cancer Res 2006, 66:2584-2591.

18. Gregorian C, Nakashima J, Dry SM, Nghiemphu PL, Smith KB, Ao Y, Dang J, Lawson G, Mellinghoff IK, Mischel PS, Phelps M, Parada LF, Liu X, Sofroniew MV, Eilber FC, Wu H: PTEN dosage is essential for neurofibroma development and malignant transformation. Proc Natl Acad Sci USA 2009, 106:19479-19484.

19. Upadhyaya M, Spurlock G, Monem B, Thomas N, Friedrich RE, Kluwe L Mautner V: Germline and somatic NF1 gene mutations in plexiform neurofibromas. Hum Mutat 2008, 29:112-122.

20. Thomas L, Kluwe L, Chuzhanova N, Mautner V, Upadhyaya M: Analysis of NF1 somatic mutations in cutaneous neurofibromas from patients with high tumor burden. Neurogenetics 2010, 11:391-400.

21. Visvader JE: Cells of origin in cancer. Nature 2011, 469:314-322.

22. Gibson P, Tong Y, Robinson G, Thompson MC, Currle DS, Eden C, Kranenburg TA, Hogg T, Poppleton H, Martin J, Finkelstein D, Pounds S, Weiss A, Patay Z, Scoggins M, Ogg R, Pei Y, Yang ZJ, Brun S, Lee Y, Zindy F, Lindsey JC, Taketo MM, Boop FA, Sanford RA, Gajjar A, Clifford SC, Roussel MF, McKinnon PJ, Gutmann DH, et al: Subtypes of medulloblastoma have distinct developmental origins. Nature 2010, 468:1095-1099.

23. Kalamarides M, Stemmer-Rachamimov AO, Niwa-Kawakita M, Chareyre F, Taranchon E, Han ZY, Martinelli C, Lusis EA, Hegedus B, Gutmann DH, Giovannini M: Identification of a progenitor cell of origin capable of generating diverse meningioma histological subtypes. Oncogene 2011, 30(20):2333-2344.

24. Singh DK, Ku CJ, Wichaidit C, Steininger RJ III, Wu LF, Altschuler SJ: Patterns of basal signaling heterogeneity can distinguish cellular populations with different drug sensitivities. Mol Syst Biol 2010, 6:369.

25. Liu J, Lau SK, Varma VA, Moffitt RA, Caldwell M, Liu T, Young AN, Petros JA, Osunkoya AO, Krogstad T, Leyland-Jones B, Wang MD, Nie S: Molecular 
mapping of tumor heterogeneity on clinical tissue specimens with multiplexed quantum dots. ACS Nano 2010, 4:2755-2765.

26. Friedman J: Gutmann DH, Maccollin M, Riccardi VM: Neurofibromatosis: Phenotype, Natural History, and Pathogenesis. Baltimore: The Johns Hopkins University Press; 1999.

27. Le LQ, Parada LF: Tumor microenvironment and neurofibromatosis type I: connecting the GAPs. Oncogene 2007, 26:4609-4616.

28. Upadhyaya M, Han S, Consoli C, Majounie E, Horan M, Thomas NS, Potts C, Griffiths S, Ruggieri M, von Deimling A, Cooper DN: Characterization of the somatic mutational spectrum of the neurofibromatosis type 1 (NF1) gene in neurofibromatosis patients with benign and malignant tumors. Hum Mutat 2004, 23:134-146.

29. McDaniel T, Carbone D, Takahashi T, Chumakov P, Chang EH, Pirollo KF, Yin J, Huang Y, Meltzer SJ: The Mspl polymorphism in intron 6 of p53 (TP53) detected by digestion of PCR products. Nucleic Acids Res 1991, 19:4796.

30. Hartmann A, Rösner U, Schlake G, Dietmaier W, Zaak D, Hofstaedter F, Knuechel R: Clonality and genetic divergence in multifocal low-grade superficial urothelial carcinoma as determined by chromosome 9 and p53 deletion analysis. Lab Invest 2000, 80:709.

31. Belchis DA, Meece CA, Benko FA, Rogan PK, Williams RA, Gocke CD: Loss of heterozygosity and microsatellite instability at the retinoblastoma locus in osteosarcomas. Diagn Mol Pathol 1996, 5:214-219.

32. Yandell DW, Dryja TP: Detection of DNA sequence polymorphisms by enzymatic amplification and direct genomic sequencing. Am J Hum Genet 1989, 45:547-555.

33. Cairns P, Polascik TJ, Eby Y, Tokino K, Califano J, Merlo A, Mao L, Herath J, Jenkins R, Westra W, Rutter UL, Buckler A, Gabrielson E, Tockman M, Cho KR, Hedrick L, Bova GS, Isaacs W, Koch W, Schwab D, Sidransky D: Frequency of homozygous deletion at p16/ CDKN2 in primary human tumors. Nat Genet 1995, 11:210-212.

34. Pollock PM, Welch J, Hayward NK: Evidence for three tumor suppressor loci on chromosome 9p involved in melanoma development. Cancer Res 2001, 61:1154-1161.

35. Li YL, Tian Z, Wu DY, Fu BY, Xin Y: Loss of heterozygosity on 10q23.3 and mutation of tumor suppressor gene PTEN in gastric cancer and precancerous lesions. World I Gastroenterol 2005, 11:285-288.

36. Liapis H, Marley EF, Lin Y, Dehner LP: p53 and Ki-67 proliferating cell nuclear antigen in benign and malignant peripheral nerve sheath tumors in children. Pediatr Dev Pathol 1999, 2:377-384.

37. Otis CN, Krebs PA, Quezado MM, Albuquerque A, Bryant B, San Juan $X$, Kleiner D, Sobel ME, Merino MJ: Loss of heterozygosity in p53, BRCA1, and estrogen receptor genes and correlation to expression of p53 protein in ovarian epithelial tumors of different cell types and biological behaviour. Hum Pathol 2002, 31:233-238.

38. Götte K, Riedel F, Neubauer J, Schäfer C, Coy JF, Hörmann K: The relationship between allelic imbalance on $17 \mathrm{p}, \mathrm{p} 53$ mutation and p53 overexpression in head and neck cancer. Int J Oncol 2001, 19:331-336.

39. McCabe A, Dolled-Filhart M, Camp RL, Rimm DL: Automated quantitative analysis (AQUA) of in situ protein expression, antibody concentration and prognosis. J Natl Cancer Inst 2005, 97:1808-1815.

40. Camp RL, Chung GG, Rimm DL: Automated subcellular localization and quantification of protein expression in tissue microarrays. Nat Med 2002, 8:1323-1327.

41. Clark SE, Warwick J, Carpenter R, Bowen RL, Duffy SW, Jones JL: Molecular subtyping of DCIS: heterogeneity of breast cancer reflected in preinvasive disease. Br J Cancer 2011, 104:120-127.

42. Lennington WJ, Jensen RA, Dalton LW, Page DL: Ductal carcinoma in situ of the breast. Heterogeneity of individual lesions. Cancer 1994, 73:118-124.

43. Campbell PJ, Yachida S, Mudie LJ, Stephens PJ, Pleasance ED, Stebbings LA, Morsberger LA, Latimer C, McLaren S, Lin ML, McBride DJ, Varela I, NikZainal SA, Leroy C, Jia M, Menzies A, Butler AP, Teague JW, Griffin CA, Burton J, Swerdlow H, Quail MA, Stratton MR, lacobuzio-Donahue C, Futreal PA: The patterns and dynamics of genomic instability in metastatic pancreatic cancer. Nature 2010, 467:1109-1113.

44. Alizadeh AA, Eisen MB, Davis RE, Ma C, Lossos IS, Rosenwald A, Boldrick JC, Sabet H, Tran T, Yu X, Powell JI, Yang L, Marti GE, Moore T, Hudson J Jr, Lu L, Lewis DB, Tibshirani R, Sherlock G, Chan WC, Greiner TC, Weisenburger DD, Armitage JO, Warnke R, Levy R, Wilson W, Grever MR, Byrd JC, Botstein D, Brown PO, et al: Distinct types of diffuse large B-cell lymphoma identified by gene expression profiling. Nature 2000, 403:503-511.
45. Whitehall VL, Wynter CV, Walsh MD, Simms LA, Purdie D, Pandeya N, Young J, Meltzer SJ, Leggett BA, Jass JR: Morphological and molecular heterogeneity within non microsatellite instability-high colorectal cancer. Cancer Res 2002, 62:6011-6014.

46. Stingl J, Caldas C: Molecular heterogeneity of breast carcinomas and the cancer stem cell hypothesis. Nat Rev Cancer 2007, 7:791-799.

47. Katz D, Lazar A, Lev D: Malignant peripheral nerve sheath tumor (MPNST): the clinical implications of cellular signalling pathways. Exp Rev Mol Med 2009, 11:e30.

doi:10.1186/1479-7364-6-18

Cite this article as: Thomas et al: Molecular heterogeneity in malignant peripheral nerve sheath tumors associated with neurofibromatosis type 1. Human Genomics 2012 6:18.

\section{Submit your next manuscript to BioMed Central and take full advantage of:}

- Convenient online submission

- Thorough peer review

- No space constraints or color figure charges

- Immediate publication on acceptance

- Inclusion in PubMed, CAS, Scopus and Google Scholar

- Research which is freely available for redistribution 